\title{
MANAJEMEN DAKWAH MAJLIS TAFSIR AL-QUR`AN
}

\author{
Oleh: \\ Andy Dermawan (andy_derma@yahoo.com) \\ UIN Sunan Kalijaga Yogyakarta
}

\begin{abstract}
Abstrak
Tulisan ini menelaah tentang manajemen dakwah yang dilakukan oleh Majlis Tafsir Al-Qur`an Pusat di Surakarta. Dengan menggunakan pendekatan sosioantropologis, kajian ini menghasilkan temuan bahwa MTA telah melakukan proses dan prosedur manajerial dalam melaksanakan kegiatan dakwah. Meski tidak tertulis secara terencana, tetapi, praktik-praktik yang dilakukan mengindikasikan hal itu. Berikutnya, letak keberhasilan dakwah MTA justru pada pola asuh jamaah pasca perekrutan anggota dan pengukuhan cabang-cabangnya. Pimpinan MTA tergolong sumber daya manusia yang tekun, terampil, istiqamah, dan bertanggungjawab atas tindakan dakwahnya, sehingga kader-kader atau jamaah menjadi militant oleh karena pendampingan dan pembinaan yang jelas, rinci dan berkelanjutan. Penting bagi organisasi sejenis, bahwa penerapan prinsip-prinsip manajemen dakwah yang dilakukan MTA menjadi contoh model di dalam melakukan pemberdayaan masyarakat muslim di Indonesia.
\end{abstract}

Kata kunci: Dakwah, manajemen dakwah, organisasi sosial-keagamaan, MTA.

\section{PREACHING MANAGEMENT IN MAJELIS TAFSIR AL QUR'AN}

\begin{abstract}
This paper examines the management of da'wah carried out by the Qur'anic Interpretation Center in Surakarta. Using a socio-anthropological approach, this study produced findings that MTA had carried out managerial processes and procedures in carrying out da'wah activities. Although not written in a planned manner, however, the practices carried out indicate that. Next, the success points of MTA preaching are precisely on the parenting style of the congregation after the recruitment of members and the inauguration of its branches. MTA leaders are classified as human resources who are diligent, skilled, istiqamah, and responsible for their da'wah actions, so that cadres become militants because of clear, detailed and continuous mentoring and guidance. It is important for similar organizations, that the application of da'wah management principles carried out by MTA is an example of a model in empowering Muslim communities in Indonesia.
\end{abstract}

Keywords: Da'wah, da'wah management, socio-religious organization, MTA. 


\section{PENDAHULUAN}

Dakwah dalam literatur Islam hukumnya fardhu ‘ain bagi setiap manusia muslim. Berdakwah adalah menyampaikan ajaran Islam yang bersumber dari Al-Qur`an dan Sunnah al-Maqbulah, agar manusia berhijrah dari keburukan menuju kebaikan dan kebenaran Islam. Menyampaikan nilainilai Islam kepada masyarakat (mad`u), membutuhkan suatu metode dan dikemas secara manajerial. Kemasan manajemen yang baik, dan didukung oleh kemampuan metode yang sesuai dengan permasalahan di masyarakat, maka persoalan-persoalan dakwah akan dapat diurai secara metodis. Tindakan manajerial yang berkelanjutan dan berproses melalui tahapan perencanaan, pengorganisasian, pengendalian, dan monitoring serta evaluasi dapat memaksimalkan sumber daya yang tersedia. Secara tehnik, semua itu dilakukan secara integratif, sistematis dan koordinatif oleh seluruh elemen organisasi agar program dan kegiatan yang telah direncanakan sesuai fungsifungsi manajemen. Kontekstualisasinya dengan dakwah, manajemen dimanfaatkan guna memastikan tiga hal.
Pertama, manajemen berfungsi untuk mengelola dan mengkoordinir program, kegiatan, dan manusianya di dalam menjalankan roda organisasi. Kedua, menempatkan dan menetapkan job discreption terhadap kegiatan-kegiatan organisasi agar berjalan sesuai dengan visi, misi dan tujuan organisasi. Ketiga, dalam rangka meningkatkan diri potensi kemanusiaan menuju kehidupan yang diridhai Allah SWT, dari buruk menjadi baik, dari kegelapan menuju pencerahan iman dan taqwa kepada Allah SWT, min al-dhulumat ila an-nur (dari kegelapan menuju kebenaran Islam). Fakta menunjukkan, bahwa metode dakwah telah melampaui kebiasaan-kebiasaan yang selama ini dilakukan, yakni ceramah (bi al-lisan) dan nasihat yang baik (mau idhah hasanah), dan dakwah materi (dakwah bi al-hal) menuju dakwah yang meliputi persoalanpersoalan kompleksitas manusia modern. Contoh konkretnya adalah dakwah melalui tulisan (dakwah bi al-kitabah), dakwah melalui Informasi dan tehnologi (e-dakwah) dan lingkungan hidup (gogreen) (Andy Dermawan: Jurnal MD, 2016).

Kajian ini mencoba melihat persoalan dakwah yang di manaj secara profesional oleh Lembaga Majlis Tafsir 
Al-Qur`an (selanjutnya disebut MTA) di kota Surakarta Jawa Tengah. Alasan mendasar yang bisa dikemukakan di sini, adalah bahwa Majlis Tafsir Al-Qur`an sebagaimana lembaga keagamaan yang lain seperti Muhammadiyah dan Nahdlatul Ulama, satu dekade terakhir mampu melakukan penyebaran secara organisasional baik itu dalam hal penyebaran gagasan atau ide-ide MTA maupun perekrutan anggota jamaah, tujuannya satu, menyebarluaskan nilainilai Islam sebagaimana dituntunkan oleh Rasululkah Saw. Secara umum dapat diamati bahwa MTA menyebar di berbagai pelosok daerah tanpa mampu “dibendung" dan di "lawan" oleh kelompok keagamaan yang lain. Hipotesis-analisis penulis menunjukkan bahwa hal itu tentu berkaitan dengan manajemen dakwah yang baik serta implementasi yang baik pula.

Ada tiga hal yang melatarbelakangi mengapa kajian ini di lakukan. Pertama, sebagai lembaga keagamaan, MTA relatif muda usianya, berdiri 19 September 1972, jika dibandingkan dengan lembaga keagamaan seperti Muhammadiyah berdiri tahun 1912 dan Nahdlatul Ulama berdiri tahun 1926. Tetapi mampu bersaing (konteksnya fastabiq al-khairat) baik dalam "kompetisi” inkubasi jumlah anggota jamaah maupun penyebaran gagasan atau ide-ide lembaga. Fakta ini cukup membuat "resistensi" sebagian lembaga keagamaan yang lain oleh karena beberapa anggota jamaahnya berpindah ke MTA.

Kedua, secara ideologis lembaga MTA di tingkat anggota jamaahnya memiliki komitmen tinggi dan militansi yang baik sehingga prinsip-prinsip dasar organisasi mampu diinternalisasikan dan diimplementasikan secara integratif. Fakta ini dapat dilihat dari program dan kegiatan masing-masing cabang MTA yang terlaksana oleh karena support dan komitmen para anggota jamaahnya. Rasa memiliki yang tinggi dan ukhuwah islamiyah yang baik anggota jamaahnya, membuat lembaga MTA mampu beradabtasi dengan berbagai model masyarakat.

Ketiga, Kedua fakta tersebut di atas mengindikasikan bahwa MTA dikelola secara baik dengan memanfaatkan manajemen dakwah, sehingga semua kegiatan dapat terlaksana dan mencapai sasaran yang dituju. Telaah ini mencoba melihat, memahami dan mendeskripsikan manajemen dakwah oleh Majlis Tafsir Al-Qur`an Surakarta dengan tujuan agar mengetahui bagaimana proses-proses manajerial itu berlangsung. Melalui 
kajian ini diharapkan problematika dakwah di Indonesia khususnya dapat ditemukan pola manajerial dakwah yang terencana dan terlaksana baik sehingga bermanfaat bagi masyarakat dakwah.

\section{PEMBAHASAN}

Reposisi Kajian dan Telaah tentang Manajemen Dakwah

Diskursus tentang manajemen dakwah, merupakan kajian dalam ranah proses manajerial sebuah lembaga Islam terhadap program dan kegiatan yang dilakukan. Menelaah Manajemen dakwah, agar mendapati hasil yang maksimal, penting kiranya menjelaskan penelitian-penelitian terdahulu agar diketahui repositioning peneliti ini di antara hasil penelitian lainnya. Beberapa penelitian yang dapat dikemukakan sebagai berikut. Ruspita Rani Pertiwi (2006) dalam penelitiannya berjudul: Manajemen Dakwah: Proses Pengelolaan Akilvitas Dakwah Berkelanjutan dari Visi Dakwah Melalui, Aksi Menuju Transformasi Mad'u. Penelitian Ruspita mencoba mempresentasikan tentang fenomena-fenomena sosial-budaya yang harus diperhatikan dalam proses dakwah. Di satu sisi pelaku dakwah harus memenuhi kebutuhan para mad'u, namun di sisi lain tidak boleh mengesampingkan apalagi mengorban- kan visi utama dakwah akibat terlalu tunduk pada kebutuhan pasar (baca: mad'u). Agar tuntunan Islam tetap berjalan, maka aspek metolodogi menjadi hal yang tak bisa ditawar lagi. Aspek ini ditekankan agar ada kesinambungan antara visi dan transformasi dakwah itu sendiri. Berikutnya, tulisan Abdul Muhaimin, tentang Manajemen Dakwah: Studi Model Dakwah Kampus Kesatuan Aksi Mahasiswa Muslim Indonesia Komisariat UIN Sunan Kalijaga Yogyakarta (Abdul Muhaminin, 2006). Tulisannya rnengetengahkan tentang manajemen dakwah yang ada di gerakan mahasiswa dan menyimpulkan bahwa fungsi-fungsi manajemen tidak dapat diterapkan secara tegas karena ilmu manajemen merupakan alat bantu terhadap keilmuan dakwah, sehingga manajemen tidak dapat berdiri sendiri sebagaimana ilmu-ilmu lain, dan ini mengefek kepada pola internalisasi manajemen dakwah ke lembaga Kesatuan Aksi Mahasiswa Muslim Indonesia di komisariat UIN Sunan Kalijaga Yogyakarta. Tulisan lain yang perlu dibaca adalah Ratna Khusnul Hatimah tentang Pelaksanaan Organizing pada Organisasi Dakwah: Studi pada Pimpinan Daerah Nasyiatul Aisyiyah Banjarnegara Periode 2002- 
2005 (Ratna Khusnul Hatimah, 2006), mengetengahkan tentang struktur organisasi yang memperbincangkan perihal personil-personil yang diposisikan pada bidang-bidang tertentu agar mahasiswa Muslim Indonesia dimaksudkan kegiatan organisasi dakwah dapat berjalan lancar sesuai dengan kompetensinya masing-masing; kemudian elemen dasar organizing yang membicarakan perihal pekerjaan (work), orang (people), lingkungan tugas (teks environment); dan proses organizing melakukan penetapan kegiatan-kegiatan dan mengelompokkannya ke dalam tugas masing-masing unit.

Menurut penulis, beberapa hasil penelitian sebagaimana telah dipaparkan di atas, belum ada yang menjadikan Majlis Tafsir Al-Qur`an sebagai subyek penelitian dan manajemen dakwah sebagai obyek kajian materinya. Oleh karena itu, kajian ini penting dilakukan dalam rangka mengetahui bagaimana manajemen dakwah lembaga MTA Surakarta sebagai sebuah kajian kasus.

\section{Majlis Tafsir Al-Qur`an: Sebuah Sketsa}

Profil resmi MTA menjelaskan, bahwa Yayasan Majlis Tafsir Al-Qur’an Pusat Surakarta adalah sebuah lembaga pendidikan dan dakwah Islamiyah yang berkedudukan di Surakarta. MTA didirikan oleh Almarhum Ustadz Abdullah Thufail Saputra di Surakarta pada tanggal 19 September 1972. Beliau seorang mubaligh yang karena profesinya sebagai pedagang mendapat kesempatan untuk berkeliling hampir ke seluruh Indonesia (kecuali Irian Jaya saat itu, sekarang bernama Papua) dan melihat bahwa kondisi umat Islam di Indonesia tertinggal karena umat Islam di Indonesia kurang memahami alQur'an. Ustadz Abdullah Thufail Saputra memimpin MTA selama 20 tahun kurang 4 hari. Beliau dipanggil ke rahmatullah pada tanggal 15 September 1992. Ketika beliau meninggal, MTA sudah tersebar ke seluruh wilayah di Karesidenan Surakarta (sekarang Solo Raya) dan Semarang, bahkan sudah tersebar sampai di Lombok Barat, Jawa Timur, DIY, Bandung, dan Jakarta (http://www.mta.or.id/sekilas-profil/ , diunduh pada 3 oktober 2016). Sebagai lembaga dakwah yang independen MTA tidak ingin menjadi underbouw dari organisasi massa atau organisasi politik manapun. Bahkan MTA tidak menghendaki berubah menjadi organisasi massa atau organisasi politik. Namun MTA juga tidak ingin menjadi lembaga yang bersifat ilegal. Untuk itu secara resmi, MTA didaftarkan sebagai 
lembaga berbadan hukum dalam bentuk yayasan dengan akta notaris $\mathrm{R}$. Soegondo Notodisoerjo Notaris di Surakarta nomor 23 tahun 1974. Kemudian untuk memenuhi ketentuan dalam Undang-Undang RI No. 28 Tahun 2004 tentang yayasan, MTA didaftarkan kembali sebagai yayasan dengan akta notaris Budi Yojantiningrum, SH, Notaris di Karanganyar, nomor 01 tanggal 6 September 2006, dan disahkan oleh Menkum dan HAM dengan Keputusan Menteri No. C2510.HT.01.02.TH 2006, yang ditetapkan tanggal 03 November 2006 dan tercatat dalam Berita Negara Tanggal 27 Februari 2007, No. 17 (Tim MTA, 2015). Sepeninggal Ustadz Abdullah Thufail Saputra, MTA dipimpin ustadz Ahmad Sukina yang dipilih secara aklamasi oleh warga MTA. Masa kepemimpinannya, MTA semakin berkembang ke berbagai penjuru Nusantara. Saat diresmikan 109 perwakilan dan cabang pada tanggal 27 Desember 2015, berjumlah 539 tersebar mulai dari Aceh hingga Merauke. Kini, MTA berkembang pesat lebih kurang 43 tahun lamanya.

Tujuan didirikannya MTA adalah untuk menyelenggarakan berbagai kegiatan dalam bidang sosial dan keagamaan, seperti penyelenggaraan pendidikan formal dan non-formal dan penyelenggaraan berbagai kegiatan pengajian dan pendirian lembaga pendidikan keagamaan yang terkait. Tujuan tersebut dimaksudkan sebagai upaya untuk mengajak umat Islam kembali ke al-Qur'an dengan tekanan pada pemahaman, penghayatan, dan pengamalan al-Qur'an dalam kehidupan sehari-hari

\section{(http://www.mta.or.id/sekilas-profil/,}

diunduh pada 4 Oktober 2016). Struktur MTA sebagai lembaga terdiri atas pusat, perwakilan, dan cabang. MTA pusat berkedudukan di Surakarta. Perwakilan MTA berkedudukan di tingkat kota/kabupaten. Cabang MTA berkedudukan di tingkat kecamatan. Dengan diresmikannya 109 perwakilan dan cabang pada Silatnas 27 Desember 2015, maka jumlah perwakilan dan cabang menjadi 539 tersebar dari Aceh hingga Merauke. Sesuai dengan tujuan pendirian MTA, yaitu untuk mengajak umat Islam kembali ke Al-Qur'an, kegiatan utama di MTA berupa pengajian Al-Qur'an. Pengajian alQur'an ini dilakukan dalam berbagai pengajian yang dapat dibedakan menjadi dua, yaitu pengajian khusus dan pengajian umum. (www.mta.or.id). 
Pengamalan Al-Qur'an membawa

ke pembentukan kehidupan bersama berdasar Al-Qur'an dan Sunnah Nabi. Kehidupan bersama ini menuntut adanya berbagai kegiatan yang terlembaga untuk memenuhi kebutuhan anggota. Salah satu kegiatan terlembaga yang dibutuhkan oleh anggota adalah pendidikan yang diselenggarakan berdasarkan nilai-nilai keislaman. Oleh karena itulah, di samping pengajian, MTA juga menyelenggarakan pendidikan, baik formal maupun nonformal, kemudian kegiatan Sosial, Satgas, SAR dan Kepemudaaan MTA, Ekonomi dan Kesehatan (Ibid.), Penerbitan, Komunikasi, dan Informasi, Kerjasama (Networking), Sumber Dana MTA dan Perkembangan Lembaga.

\section{Dialektka Dakwah dan Manajemen}

\section{Dakwah}

Terry (Winardi, 1982; Moekijat, 1989) mengatakan manajemen merupakan proses yang terdiri dari tindakan-tindakan perencanaan, pengorganisasian, penggerakan, dan pengawasan yang dilakukan untuk menentukan serta mencapai tujuan yang telah ditetapkan melalui pemanfaatan sumber daya manusia serta sumbersumber lainnya. Pendapat Terry tersebut mencoba menjelaskan manajemen merupakan suatu proses yang dilakukan dalam rangka mencapai tujuan atau sarana-sarana yang telah ditetapkan organisasi dengan mengharuskan sumber daya manusianya memiliki kompetensi akademik dan ketrampilan yang kuat dalam suatu organisasi tertentu. Dengan potensi sumber daya yang dimiliki, diharapkan suatu organisasi yang terkelola dengan baik relatif mampu mengorganisir kegiatan yang ada pada suatu organisasi tertentu secara baik, dan tercapai pula tujuan yang dicita-citakan bersama. Penjelasan tersebut di atas menegaskan bahwa adanya tujuan yang jelas dalam organisasi, membuat individu-individu di dalamnya mampu mengekspresikan dan mengapresiasi kompetensi dibidang masing-masing. Manajemen sebagai suatu proses dan sekaligus batasan fungsi-fungsinya yang terdiri dari planning, organizing, actuating, dan controlling, yang masingmasing bidang dapat digunakan secara berurutan dalam upaya untuk mencapai sasaran yang telah ditetapkan (Winardi, 1982). Pertama, perencanaan (planning), merupakan kegiatan menetapkan tujuan serta merumuskan dan mengatur pendayagunaan manusia, materiil, informasi, finansial, metode dan waktu untuk memaksimalkan efisiensi dan efektifitas pencapaian tujuan (Ulbert 
Silalahi, 1996). Kedua, pengorganisasian

(organizing), yakni menyangkut tentang penentuan kegiatan-kegiatan yang dibutuhkan untuk mencapai sasaran, pengelompokan kegiatan-kegiatan ke dalam departemen-departemen, penugasan kelompok-kelompok kegiatan tersebut kepada manajer, pelimpahan wewenang untuk melaksanakannya, dan penetapan koordinasi horizontal dan vertikal dan kegiatan-kegiatan, wewenang, dan komunikasi (Harold Koontz, 1989). Ketiga, Penggerakan (actuating), yakni keseluruhan upaya dan cara untuk mendorong para anggota organisasi agar bersedia bekerja sebaik mungkin demi tercapainya tujuan organisasi secara efektif, efisien, dan ekonomis. Penggerakan merupakan fungsi manajerial khususnya pada bidang administrasi dan pengagendaan program kerja. Selanjutnya adalah pengawasan (controlling), yakni proses pengamatan seluruh kegiatan organisasi agar lebih menjamin bahwa semua pekerjaan yang sedang dilakukan sesuai dengan rencana yang telah ditentukan bersama. Dari sini tampak sekali bahwa pengawasan merupakan suatu upaya pencegahan agar tidak terjadi penyimpangan-penyimpangan dan pelaksanaan kegiatan organisasi yang telah direncanakan. Karena itu, pengawasan memiliki makna lain yang sepaham, yakni evaluasi terhadap kegiatan organisasi yang dilaksanakan (Andreas Lako, 2004).

Kajian tentang manajemen dakwah, merupakan pemaduan secara integratif, Dakwah dan Manajemen (Andy Dermawan, 2016). Dakwah (Warson Munawwir, 1984; Andy Dermawan, 2002), merupakan sebuah proses "penyadaran" manusia, dari kehidupan kegelapan menuju kehidupan yang diridhai oleh Allah SWT. Dakwah juga berarti sebuah perjalanan "hijrah" dari keburukan menuju kebaikan. Di dalam berdakwah mensyaratkan sebuah manajemen yang baik guna memastikan dakwah yang disampaikan bisa diterima langsung oleh masyarakat (mad $`$ ). Pengelolaan dakwah yang baik akan menghasilkan perubahan dan meningkatkan efektifitas dakwah, oleh karena itulah penting di sini memaksimalkan fungsi manajemen agar semua program dan kegiatan suatu organisasi dapat berjalan sebagaimana mestinya. Jadi, pada hakikatnya manajemen dakwah adalah sebuah pengaturan secara sistematis dan koordinatif dalam aktifitas dakwah dari awal hingga akhir aktifitas dakwah (Andy Dermawan, 2016). Penting dijelaskan di sini, bahwa urgensi 
manajemen dan dakwah merupakan “satu keping koin mata uang”, sisi satu dan sisi lainnya berbeda tetapi tidak bisa dipisahkan ataupun disamakan. Suatu aktifitas dakwah mampu berjalan baik apabila pengetrapan fungsi manajemen berfungsi sebagaimana mestinya.

\section{PEMBAHASAN}

\section{Manajemen Dakwah Majlis Tafsir}

\section{Al-Qur`an}

Menurut peneliti M.C. Ricklefs dalam karyanya berjudul Islamisation and Its Opponent in Java, terbitan NUS Press, Singapore tahun 2012, yang dindonesiakan menjadi "Mengislamkan Jawa: Sejarah Islamisasi di Jawa dan Penentangnya dari tahun 1930 sampai Sekarang”, tahun 2013 menjelaskan,

"Bahwa tidak semua kelompok Dakwahis dan Islamis kecil memandang kekerasan sebagai sesuatu yang dapat diterima. Di Surakarta, dua gerakan pemurnian Islam, MTA dan Assalam, yang mulai berdiri pada dasawarsa 1970-an beroperasi, menyumbang bagi proses Islamisasi masyarakat yang lebih dalam. Mereka melakukan semuanya itu tanpa menggunakan kekerasan, tetapi dengan mengandalkan pendidikan dan pengajian dan, kiranya dapat disimpulkan demikian, lebih efektif dalam membawa perubahan sosial daripada berbagai kelompok laskar yang suka mengayun-ayunkan pedang. Tentu saja, mereka pun juga tidak terbebas dari kontroversi dari waktu ke waktu” (M.C. Ricklefs, 2013).
Menjadi catatan penting pendapat seorang peneliti Barat, yakni M.C. Ricklefs, memandang gerakan Islam di Indonesia, khususnya MTA, menjadi perhatiannya dan ini menunjukkan bahwa MTA di dalam sejarah perjalanan dakwahnya memiliki visi dan tujuan yang jelas sekaligus menunjukkan bahwa lembaga MTA selama ini mendapat tempat di masyarakat. Terbukti dari proses inkubasi para anggota jamaahnya, yang rata-rata dari masyarakat awam sampai terpelajar hingga tokoh masyarakat. Majlis Tafsir Al-Qur`an adalah Lembaga Pendidikan dan Dakwah Islamiyah yang ikut serta mencerdaskan bangsa melalui dakwah dan pendidikan di dalam melakukan perubahan sosial. Hal itu dapat dilihat dari rangkaian program dan kegiatan, sebagaimana dapat dilihat pada Bab Dua, sekaligus menunjukkan suatu pengelolaan yang baik, terencana dan evaluatif. Proses dan aplikasi fungsi manajemen inilah yang mengukuhkan bahwa MTA dikelola secara profesional. Pada pembahasan ini, peneliti mencoba mengetengahkan bagaimana MTA mengelola secara baik kegiatan dakwah Islamiyah melalui manajemen dakwah. Untuk itu, penting melihat dan memahami proses-proses manajerial itu 
berlangsung. Adapun aplikasi dan fungsi-fungsi manajemennya sebagai berikut.

\section{Perencanaan Dakwah (Takhthith),} (Munir dan Wahyu Ilahi, 2016).

Perencanaan dakwah, adalah menentukan langkah-langkah atau perencanaan yang jelas mengenai kegiatan atau program kegiatan sehingga sasaran yang telah direncanakan dapat dituju dengan baik, termasuk juga media dakwah dan personil-personilnya. Di samping itu, juga menentukan materi yang sesuai dengan situasi dan kondisi mad `u. Jadi, jika semua telah memiliki kejelasan sejak penentuan langkahlangkah hingga membuat asumsi-asumsi, maka tingkat kematangan persiapan itu sudah baik. Bahkan Allah SWT di dalam melakukan proses penciptaan dilakukan secara matang sesuai dengan tujuan yang jelas (Didin Hafidhuddin dan Hendri Tanjung, 2003).

Suatu kegiatan yang direncanakan matang, kemudian di kawal proses pelaksanaannya, cenderung menjadi kegiatan yang bermutu dan berefek baik kepada para anggota jamaah. MTA Surakarta, di dalam merencanakan dakwahnya berbeda dengan beberapa organisasi lainnya, yang cenderung “fokus” merencanakan pada program dan kegiatan saja, namun bagi MTA yang direncanakan itu adalah pada ketetapan pilihan waktu kegiatan khususnya pengajian dan kegiatan lainnya. Menurut salah seorang Pimpinan, mengatakan bahwa MTA tidak melakukan perencanaan program pengajiannya secara rinci, tetapi MTA dalam program dan kegiatan khususnya pengajian, merespon probematika umat yang di hadapi atau secara tematik di bahas dalam pengajian. Meski tidak selalu membahas tafsir, namun juga mu`amalah dan lain sebagainya. Satu hal yang membuat pengajian di MTA berjalan rutin dan berkelanjutan adalah semangat para jamaah pengajian yang datang dari berbagai penjuru wilayah secara antusias mendatangi pengajian di MTA guna mencari jawaban yang selama ini mereka butuhkan sesuai dengan hari yang ditentukan. Dan di MTA mereka merasa pertanyaanpertanyaan itu dapat dijawab secara memuaskan. Semangat dan antusias itulah yang menjadikan kegiatan pengajian itu berjalan disiplin dan berkelanjutan (Hasil wawancara dengan Mgtn, 16 September 2016).

Berdasarkan informasi di atas, dapat diketahui bahwa kekuatan MTA di dalam menjalankan program dan kegiatannya terletak pada pola 
pembinaan jamaah yang berkelanjutan dan penuh perhatian dari para Pimpinan Pusat hingga Pimpinan Cabang dan para guru atau muballigh. Bukan hanya perencanaan matang saja. Wajar jika kegiatan MTA mampu berjalan sukses dan berkelanjutan karena kontrol kuat (dalam menjaga keberlangsungan kegiatan) dari para jamaah atau peserta pengajian yang ikut serta menjaga keberlanjutannya. Di samping itu, ada "garansi waktu” kegiatan yang menjadikan kegiatan pengajian di MTA digemari oleh masyarakat umum, karena waktu mulai dan berakhirnya kegiatan pengajian sangat jelas dan tegas, kapan mulainya dan kapan berakhir acaranya(Hasil wawancara dengan salah satu jamaah MTA, 28 Oktober 2016).

Selanjutnya, penentuan program MTA, pemilihan materi kajian serta konsistensi di dalam melaksanakan kegiatan menjadi kunci sebuah perencanaan yang baik dalam organisasi, inilah yang disebut jalinan koodinasi kegiatan. Kata kunci perencanaan menurut Stephen P. Robbins, bahwa perencanaan pengorganisasian itu terletak pada proses koordinasi dan integrasi kegiatan-kegiatan kerja agar efisien dan efektif dengan melibatkan orang lain untuk bekerja sama. Memahami dinamika organisasi MTA di ranah program dan kegiatan di lapangan menunjukkan bahwa MTA mampu mengubah individu-individu menjadi Tim yang terkoordinasi solid (Stephen P. Robbins, 2003).

\section{Pengorganisasian Dakwah}

\section{(Thanzhim)}

Pengorganisasian adalah proses pengelompokan individu, tugas, tanggungjawab dan wewenang sehingga suatu organisasi dapat bergerak leluasa di dalam satu kesatuan tindakan organisasi (M. Munir dan Wahyu Ilahi, 2006). Bukan hanya pada persoalan bagaimana elemen-elemen itu digerakkan dalam suatu wadah tetapi keteraturan dan sistematika yang baik juga menjadi arahan dan fokus utamanya.

Pengajian di MTA dijalankan melalui cara penentuan "Gelombang Pengajian”. Penentuan "gelombang” itu semacam pengelompokan dalam belajar atau kajian. Ada gelombang pertama, ada gelombang kedua dan begitu seterusnya. Kata "gelombang” tidak dimaksudkan suatu tahapan atau strata, tetapi lebih sebagai "angkatan pengajian”. Cara pengorganisasian semacam ini, cenderung memudahan di dalam penyampaian materi sesuai 
dengan kadar penerimaan materi masing-masing anggota. Di samping itu, kehadiran jamaah di dalam mendatangi kegiatan perlu dikelola atau diorganisir melalui angkatan atau dalam gelombanggelombang yang ada. Para pimpinan atau guru pengajar di dalam mengajarkan nilai-nilai Islam, secara serius melakukan pendampingan dan secara organisasional melalui proses pengenalan, pembinaan, pemantapan dan pengendalian. Anggota dibina melalui pengajian rutin dan di forum-forum pengajian yang dilakukan secara berjamaah dan semua persoalan dirujuk dari Al-Qur`an dan As-Sunnah. Adapun kitab-kitab rujukan lainnya dijadikan sebagai perbandingan guna melihat persoalan secara jernih. Pola pembinaan yang berkelanjutan dan ikhlas serta serius inilah yang mampu menghadirkan ribuan jamaah pengajian. Catatan penting yang perlu diketahui, bahwa para pimpinan di MTA Surakarta khususnya, memiliki jiwa istiqamah, ikhlas, dan sabar membina jamaah dan masyarakat. Semua kegiatan di MTA diorganisir baik sehingga jamaah merasa nyaman dan terikat kehadirannya oleh karena hubungan silaturahiem yang terjaga. Ada pengajian khusus bapakbapak yang dilaksanakan setiap hari jumat sore menjelang maghrib, pengajian itu khusus bapak-bapak anggota MTA, jumlahnya mencapai tiga ribu lima ratusan, ada juga pengajian ibu-ibu khusus hari rabu, jumlahnya mencapai tiga ribuan. Bahkan setiap ahad pagi diperuntukkan untuk umum, jumlah jamaahnya juga ribuan dan itu sudah berjalan rutin (Hasil wawancara dengan pak Suratman, 16 September 2016).

Pada hakikatnya, kegiatan apapun jika dikelola dengan baik dan benar, akan membawa hasil yang memuaskan. Apalagi kekompakan dalam menjalankan kegiatan menjadi roda penggeraknya, sudah barang tentu cenderung menjadi semangat dan motivasi tiada henti. Terlebih ini kegiatan yang menyoal spiritualitas manusia, tentu membutuhkan keikhlasan, kesabaran, ketelitian dan pengorganisasian yang baik. Inti dari pengorganisasian dakwah semacam ini pokok denotatifnya pada keistiqamahan yang berkelanjutan. Inilah yang menentukan apakah suatu kegiatan itu akan segera berakhir dengan keadaan yang memprihatinkan atau bertahan dengan kondisi yang meningkat lebih baik lagi.

Kajian manajemen pengorganisasian menjelaskan, bahwa studi-studi secara konsisten memperlihatkan bahwa 
hubungan kekompakan dengan

produktifitas tergantung pada norma kinerja yang dibangun oleh kelompok tersebut. Semakin kompak kelompok tersebut, para anggota semakin mengarah kepada tujuannya. Jika norma kinerja tinggi (misalnya, out put tinggi, pekerjaan berkualitas, kerja sama dengan individu di luar kelompok), maka suatu kelompok yang kompak akan lebih produktif daripada kelompok yang kurang kompak (Robbins, 2002). Selain fakta menunjukkan bahwa MTA mampu mengubah individu menjadi Tim, sisi lainnya adalah kemampuan mengorganisir kegiatan secara kompak oleh para jamaahnya. Kekompakan itu tidak didapat secara cuma-cuma. Melainkan bentuk kepuasan jamaah atas respon cepat tanggap oleh pimpinan organisasi manakala arus bawah ranah Cabang melontarkan beragam permasalahan umat dan mampu dijawab atau diselesaikan oleh pimpinan dengan baik dalam sebuah forum bersama. Dari sini, wajar jika seluruh elemen jamaah bersatu padu dan kompak “mengeksekusi” kegiatan secara berjamaah pula.

3. Penggerakan Dakwah (Tawjih), (M. Munir dan Wahyu Ilahi, 2006).
Penggerakan dakwah konteks ini adalah bentuk pemberian dorongan dalam hal motivasi untuk melakukan kegiatan yang didasarkan pada pengabdian dan "profesionalisme”. Penggerakan konteks ini adalah meluruskan niat dan cara berpikir bahwa kerja itu tidak hanya untuk mendapatkan bayaran berupa uang, tetapi proses penggerakan itu ada unsur ikhlas dan dikerjakan dengan niat baik pula. Di sinilah dibutuhkan pemberian motivasi, semangat kerja, bimbingan, jalinan komunikasi yang baik, dan pengembangan peningatan pelaksanaan menuju lebih baik lagi. Dengan demikian, maka dapat disimpulkan bahwa dorongan dan pemberian motivasi cenderung membawa semangat tinggi dan melaksanakan program dan kegiatan secara baik serta sungguh-sungguh.

Pada dasarnya, penggerakan dakwah memiliki kontekstual dengan motivasi dalam organisasi, motivasi itu bisa dalam bentuk dorongan untuk maju, bertahan dan bergerak ke depan meraih apa yang telah dicita-citakan bersama (Andy Dermawan, 2016). Organisasi yang syarat dengan motivasi cenderung memiliki tingkat ketahanan atau survive yang baik, sebab seluruh elemen organisasi senantiasa disemangati dan 
dipenuhi oleh situasi dan keadaan yang baik dalam menatap masa depan.

Para pimpinan MTA senantiasa memberi dorongan dan semangat hidup yang tinggi sehingga jamaah merasa optimis, tenang, yakin dan pasti di dalam menjalani hidup. Menurut salah seorang peserta pengajian rutin hari Jumat menyatakan, bahwa hampir disetiap pengajian, jamaah dimotivasi oleh pimpinan MTA agar semangat menjalani hidup dengan baik, benar dan yakin akan kebenaran Islam. Dan semangat itu didapat dari keyakinan kita pada kebenaran Al-Qur`an dan As-Sunnah (Hasil wawancara dengan salah seorang jamaah, 28 Oktober 2016).

Motivasi adalah dorongan kehendak yang menyebabkan seseorang melakukan suatu perbuatan untuk mencapai tujuan tertentu. Motivasi berasal dari kata motif yang berarti "dorongan" atau rangsangan atau "daya penggerak" yang ada dalam diri seseorang. Motivasi didefenisikan sebagai kondisi internal yang membangkitkan seseorang untuk bertindak, mendorong untuk mencapai tujuan tertentu, dan membuat seseorang tetap tertarik dalam kegiatan tertentu. Motivasi diartikan juga sebagai dorongan internal dan eksternal dalam diri seseorang yang diindikasikan dengan adanya; hasrat dan minat; dorongan dan kebutuhan; harapan dan cita-cita; penghargaan dan penghormatan. Motivasi adalah sesuatu apa yang membuat seseorang bertindak juga merupakan dampak dari interaksi seseorang dengan situasi yang dihadapinya.

(http://www.pengertianahli.com).

Beberapa contoh motivasi yang dilakukan oleh pimpinan MTA, adalah menyampaikan secara terus-menerus agar hidup sesuai tuntunan Al-Qur`an dan As-Sunnah, menjauhi yang bathil, membiasakan hidup islami dan bekerja keras, bekerja cerdas serta senantiasa bekerja sama sesama Tim jamaah dan menghormati khususnya sesama jamaah MTA. Imbas dari motivasi ini akan terbawa secara individu di luar organisasi, yakni menghormati sesama, bekerja sama dan tetap menjadikan AlQur`an sebagai tuntunan hidup seharihari.

4. Pengendalian dan Evaluasi Dakwah (Riqabah), (Ibid.).

Pengendalian dan evaluasi dakwah dalam hal ini adalah menelaah dan menelisik kembali proses-proses yang telah dilakukan sejak dari rencana hingga target selama pelaksanaan itu 
berlangsung apakah berhasil atau tidak. Menurut A. Rasyad Saleh, langkahlangkah dalam pengendalian itu sebagai berikut, pertama menetapkan standar atau alat pengukur, mengadakan pemeriksanaan dan penelitian terhadap pelaksanaan tugas dakwah yang telah ditentukan, membandingkan antara pelaksanaan tugas dengan standar mutu yang telah ditetapkan dan mengadakan tindakan perbaikan (A. Rosyad Saleh, 1993). Dengan kata lain, tindakan monitoring merupakan cara untuk mengendalikan kegiatan dalam organisasi. Secara organisasional, monitoring adalah kegiatan untuk mengikuti suatu program dan pelaksanaanya secara mantap, teratur dan terus menerus dengan cara mendengar, melihat dan mengamati dan mencatat keadaan serta perkembangan program tersebut. Monitoring merupakan fungsi manajemen yang berkesinambungan yang mempunyai tujuan utama menyediakan umpan balik dan indikasi awal tentang bagaimana kegiatan-kegiatan dilaksanakan, perkembangan atau pencapaian kinerja dari waktu ke waktu serta pencapaian hasil yang diharapkan. Monitoring dan pengendalian adalah sebuah kesatuan kegiatan, yang sering juga disebut sebagai on-going evaluation atau former evaluation.. Setiap monitoring dalam organisasi, terintegrasi dengan evaluasi dan pengendalian. Oleh karena itu, monitoring dan evaluasi merupakan kegiatan yang dilakukan untuk mengecek ulang suatu kegiatan agar ke depan menjadi lebih baik lagi. Kontekstualisasinya dengan MTA, pengendalian dan evaluasi terhadap kegiatan itu dilakukan setiap hari ahad guna merespon problematika atau umpan-balik terhadap apa yang disampaikan oleh wakil-wakil cabang dan daerah tentang apa yang terjadi di masyarakat. Menurut pernyataan salah seorang Pimpinan MTA, bahwa setiap ahad pagi di kantor pusat MTA Surakarta ada pengajian bersifat umum. Jamaahnya berjumlah ribuan dan dari berbagai wilayah. Usai shalat zuhur dan makan siang bersama, seluruh Pimpinan Pusat hingga Cabang serta guru-guru atau muballigh berkumpul melakukan evaluasi kegiatan dan mendiskusikan persoalan-persoalan serta respon-respon penting dari masalah-masalah keumatan. Ajuan pertanyaan-pertanyaan yang dibawa pimpinan cabang atau guru-guru pengajar disampaikan di forum itu untuk dibahas dan ditemukan jawabannya agar ketika nanti disampaikan kepada masyarakat dapat segera ditindaklanjuti. Forum ini juga sekaligus forum 
silaturahiem antar pimpinan guna mempererat silaturahiem dan menjaga keberlangsungan MTA ke depan (Hasil wawancara dengan Mgtn, 28 Oktober 2016). Data yang peneliti dapatkan hasil wawancara dengan bapak Sukina, menyatakan bahwa MTA setiap ahad siang melakukan pertemuan Pimpinan bahkan bisa dikatakan se-Indonesia guna merespon problematika yang terjadi agar dapat diantisipasi lebih dini dengan cara yang baik. Melalui forum inilah, selain sebagai ajang evaluasi, juga dialog secara langsung dari sumbernya mengenai persoalan-persoalan yang terjadi di berbagai cabang, daerah dan wilayah, masing-masing cabang menyampaikan persoalan-persoalan yang dihadapi secara rinci, sehingga cara merespon seperti yang dilakukan oleh para pimpinan MTA itu lebih mendalam dan akurat datanya, bukan berdasarkan "katanya” (Hasil wawancara dengan Pimpinan MTA bapak Sukina, 28 Oktober 2016).

Paparan di atas menunjukkan, bahwa pimpinan MTA di dalam mengendalikan organisasi menjadikan ruang silaturahiem, salah satunya melalui kegiatan pengajian yang menjadi ujung tombak organisasi MTA, sebagai sarana untuk mengetahui perkembangan cabang yang ada di daerah-daerah serta "kontrol internal” dinamika MTA yang tengah berjalan mengarungi ruang dan waktu. Adapun berbagai permasalahan yang terjadi menjadi materi dan bahan diskusi guna memahami permasalahan di masyarakat dan organisasi serta ikut andil membangun bangsa melalui pendidikan. Wajar, jika militansi anggota MTA yang tersebar di berbagai daerah di seluruh Indonesia mengakar kuat oleh karena pimpinan MTA memiliki rasa tanggungjawab, komitmen dan pendampingan yang secara terusmenerus. Itulah militansi dari hulu ke hilir.

\section{KESIMPULAN}

Masalah telah diurai. Problematika telah dipaparkan, hingga menemukan "benang merah”, bahwa Majlis Tafsir Al-Qur`an Surakarta adalah organisasi lembaga dakwah yang independen dan tidak ingin menjadi underbouw dari organisasi massa atau organisasi politik manapun. Majlis Tafsir Al-Qur`an adalah Lembaga Pendidikan dan Dakwah Islamiyah yang ikut serta mencerdaskan bangsa melalui dakwah dan pendidikan di dalam melakukan perubahan sosial. Kontekstualisasinya dengan manajemen dakwah, pertama, bahwa MTA merencanakan kegiatan dakwah dengan baik. Meski tidak selalu 
secara rinci, tetapi apa yang sedang dihadapi umat saat itu, direspondan dicarikan solusinya. Kedua, kegiatan pengajian di MTA dijalankan melalui cara penentuan “Gelombang Pengajian”. Kata “gelombang” tidak dimaksudkan suatu tahapan atau strata, tetapi lebih sebagai “angkatan pengajian”. Cara pengorganisasian semacam ini, cenderung memudahan di dalam penyampaian materi sesuai dengan kadar penerimaan materi masing-masing anggota. Ketiga, motivasi diberikan menggunakan momentum pengajian jamaah, baik itu di internal pimpinan atau pengurus, maupun jamaah pada umumnya. Bentuk motivasi lebih diarahkan kepada penguatan iman dan taqwa serta memastikan bahwa Islam adalah kebenaran dari Allah SWT. Keempat, evaluasi dilakukan secara rutin setiap hari ahad pada pertemuan pimpinan cabang hingga pusat, sehingga dakwah dapat dikendalikan sesuai dengan visi dan tujuan organisasi MTA. Adapun temuan menarik di lapangan terkait dengan manajemen dakwah adalah Pengendalian yang dilakukan itu melalui proses pengenalan, kemudian pendampingan dan pembinaan secara berkelanjutan, dan pemantapannya sebagai bentuk militansi jamaah MTA.
Sebagai rekomendasi dan saran, perlu dilihat sisi lain dari organisasi MTA, tidak hanya perspektif manajemen dakwah saja, tetapi juga sosial-budaya, politik, ekonomi, dan kontribusi besarnya terhadap NKRI dapat dijadikan kajian yang menarik. Di samping itu, kajian-kajian dalam bentuk lain tentang organisasi MTA perlu dilakukan guna memberikan pendidikan tentang pola pemberdayaan masyarakat yang dilakukannya.

Terakhir, sebagai kritik dan saran dari hasil kajian ini untuk MTA sebagai berikut. Pertama, tulisan-tulisan tentang organisasi MTA, selain produksi hasil fatwa-fatwa pengajian, masih cukup langka. Kalaupun ada lebih banyak diwarnai oleh para pemerhati MTA (peneliti, komentator, pembaca) tentang dirinya. Karya-karya tentang diri MTA dari “orang dalam” MTA penting dilakukan, sebagai respon-balik atas kritikan dan tudingan yang tidak mendasar. Kedua, pentingnya mempublikasikan pandangan-pandangan MTA tentang aqidah islamiyah, politik, sosial, budaya, ekonomi, pendidikan, dakwah, dan filantropi Islam.

\section{DAFTAR PUSTAKA}

Abdul Muhaimin, "Manajemen Dakwah (Studi Model Dakwah Kampus 
Kesatuan Aksi Mahasiswa Muslim Indonesia Komisariat UIN Sunan Kalijaga Yogyakarta”, dalam Skripsi, Jurusan Manajemen Dakwah Fakultas Dakwah UIN Sunan Kalijaga Yogyakarta, 2006, tidak diterbitkan.

Andy Dermawan, “Manajemen Dakwah Kontemporer di Kawasan Perkampungan: Studi pada Kelompok Pengajian Asmaul Husna Potorono Banguntapan Bantul”, dalam Jurnal MD, Vol. 2 Nomor 1, UIN Sunan Kalijaga Yogyakarta, tahun 2016.

Andy Dermawan, "Peran Motivasi dalam Organisasi”, dalam Makalah (tidak diterbitkan) kegiatan Pemberdayaan Mahasiswa Jurusan Manajemen Dakwah fakultas Dakwah dan Komunikasi UIN Sunan Kalijaga Yogyakarta, 8 September 2015.

Andy Dermawan dkk, Metodologi Ilmu Dakwah, Yogyakarta: Penerbit Lesfi, 2002.

Ahmad Warson Munawwir, Kamus A1Munawwir: Arab-Indonesia, Yogyakarta: Pondok Pesantren Krapyak, 1984.

Andreas Lako, Kepemimpinan dan Kinerja Organisasi: Isu, Teori dan Solusi, Yogyakarta: Amara Books, 2004.

A. Rosyad Saleh, Manajemen Dakwah Islam, Jakarta: Bulan Bintang, 1993.

Didin Hafidhuddin dan Hendri Tanjung, Manajemen Syariah dalam Praktik, Jakarta: Gema Insani Press, 2003.

Dedy Mulyana, Metode Penelitian Kualitatif, Paradigma Baru Ilmu Komunikasi dan Ilmu Sosial
Lainnya, Bandung: PT. Remaja Rosdakarya, 2002.

Harold Koontz, Intisari Manajemen, Jakarta: PT. Bina Aksara, 1989.

Jennifer M. George dan Gareth R. Jones, Contemporary Management: Creating Value in Organizational, New York: McGraw-Hill Irwin, 2003

Lexy J. Moleong, Melodologi Penelitian Kualitatif, Bandung: PT. Remaja Rosdakarya, 2000.

Moekijat, Tanya Jawab Asas-asas Manajemen, Bandung: Mandar maju, 1989.

M. Munir dan Wahyu Ilahi, Manajemen Dakwah, Jakarta: Rahmat Semesta, 2006.

M.C. Ricklefs, Mengislamkan Jawa: Sejarah Islamisasi di Jawa dan Penentangnya dari tahun 1930 sampai Sekarang, terj. FX. Dono Sunardi dan Satrio Wahono, Jakarta: PT. Serambi Ilmu Semesta, 2013.

Ratna Khusnul Hatimah, "Pelaksanaan Organizing pada Organisasi Dakwah: Studi pada Pimpinan Daerah Nasyiatul Aisyiyah Banjarnegara Periode 20022005”, dalam Skripsi, Jurusan Manajemen Dakwah Fakultas Dakwah UIN Sunan Kalijaga Yogyakarta, 2006.

Ruspita Rani Pertiwi, "Manajemen Dakwah: Proses Pengelolaan Aktivitas Dakwah Berkelanjutan dan Visi Dakwah Melalui Aksi Menuju Transformasi Mad'u”, dalam Jurnal Dakwah, Fakultas Dakwah UIN Sunan Kalijaga Yogyakarta, Vol. VII, No. 2, JuliDesember, 2006.

Stephen P. Robbins tentang "Mengubah Individu Menjadi Pemain Tim”, 
dalam Perilaku Organisasi-Jilid1, terj. Tim Indeks, Jakarta: Indeks Kelompok Gramedia, 2003.

Stephen P. Robbins, Prinsip-Prinsip Perilaku Organisasi: Edisi Kelima, terj. Halida dan Dewi Sartika, Jakarta: Penerbit Erlangga, 2002.

Tim MTA, "Silaturahim Nasional MTA”, dalam Buku Profil dan Mengenal MTA, diselenggarakan oleh Silatnas ke-2 se-Indonesia di Jakarta tahun 2015.

Ulbert Silalahi, Pemahaman Praktis Asas-asas Manjemen, Bandung: Mandar Maju, 1996.

Winardi, Asas-asas Manajemen, Bandung: Penerbit Alumni, 1982. http://www.pengertianahli.com/2013/09 /pengertian-motivasi-menurutpara-ahli.html,

http://www.chpm.fk.ugm.ac.id/index.ph $\mathrm{p} / \mathrm{id} /$ home/root/mainmenu/85id/pml-ntt/640-modul-vimonitoring-pengendalian-evaluasidan-pelaporan-pelayanankesehatan-tingkat-pertama-dipuskesmas,

http://ejournal.uinsuka.ac.id/index.php/JMD.

http://www.mta.or.id/sekilas-profil/ http://www.mta.or.id/kontak-kajian/ http://www.mta.or.id/brosur-mta/ 